\title{
3
}

\section{The Evolution of Russia's IT Sector}

This chapter describes the formation of the ICT field in post-Soviet Russia. The first section introduces the reader to the realities of a start-up Russian software firm and the role of personal networks in the company growth through a detailed description of the birth and development of Arcadia, one of the central software companies in St. Petersburg. The second section places this case in a larger historical context by depicting in a necessarily limited form the evolution of computing in the Soviet Union. The third section describes the role of information technology in the collapse of the Soviet Union, drawing on the work of Manuel Castells. The last section focuses on ICT in post-Soviet Russia by describing its role in the Russian national economy, the use of ICT by the Russians, the state's supportive measures in the IT field, and the position of Russian IT in the global economy.

\section{Arcadia: The birth of a St. Petersburg software company}

Arcadia's story is told here to illustrate the role of personal networks in the early phase of the emerging Russian software industry. The story relies on the account of Arcadia's founder and CEO Arkady Khotin, and will be reproduced here on the basis of a series of meetings and e-mail exchanges between the author and Khotin, and the article by Cook (2009). ${ }^{1}$

Khotin was one of the thousands of Soviet engineers, computer scientists, and mathematicians whom the collapse of both the economy and governmental support for scientific research forced to find new jobs. Many emigrated, but those who did not had to make a living at a time when the economy and society were floating from one crisis to another, 
when the institutions of the market economy had not yet been created but the Soviet ones had started to fall apart.

Khotin's recollections describe vividly the background of the first Russian IT entrepreneurs coming from the ranks of research institutes, the difficulties they faced in the early years of the formation of the software industry, and the central role of social relations in overcoming these problems. The story will be presented in chronological order, depicting the most important steps taken and the resources accumulated during Khotin's professional career.

\section{Potatoes and punchcards at a scientific research institute (1972-8)}

After graduating from the Leningrad Institute of Aviation Engineering as a radio engineer, Khotin served two years in the Red Army base near Tallinn, the capital of Estonia. After serving in the army Khotin, now a reserve lieutenant, landed a job in 1972 as a hardware developer in a research institute, conducting studies in the field of hydrological technology in his native Leningrad. Khotin's institute was secret, as were many Soviet research institutes - even the researchers in the different departments were not supposed to know what was being studied next door. As Khotin's work was not in any way related to computers and his laboratory did not have one, he was introduced to the world of computing by a lucky coincidence.

In the Soviet era, the employees of the institute were sent once a year to help nearby state farms to harvest potatoes. During these trips, which were called kartoshka (potato) by the staff, there was not much to do in the evenings but drink vodka and get to know the researchers from the other laboratories. Bumping into one of these acquaintances at the institute later on proved crucially important for Khotin's future:

I ran into this guy in the corridor of our institute. He was carrying a huge pile of Hollerith cards [punch cards used for programming]. I did not know what they were because our laboratory did not have any computers and I jokingly swiped the whole pile to the floor. He got very angry and shouted that he'd been working on them for months and I had ruined everything. I apologized, helped him to pick the cards up and sat with him several evenings helping to resort them. While doing this I grew interested in programming and computers. 'What is this computer? What do you do with it?'

Khotin started to study programming voluntarily in evening courses. One of his young teachers - today a professor of computer science at a 
prestigious St. Petersburg university - told the course participants that they needed to start learning programming or they would find themselves on the street in a few years' time.

\section{Computerizing Soviet factories at the state computing firm 'LSMNU' (1979-89)}

Khotin took this advice seriously and left the research institute in 1979 for the state firm LSMNU, ${ }^{2}$ which specialized in the computerization of Soviet factories under the ministry of industrial instrumentation and engineering (Minpribor). The Ministry had given orders to allocate computers to individual factories, many of which did not understand or know how to operate them. It was Khotin and his work brigade who were responsible for helping the factories under the command of the ministry nation-wide to install copies of Western minicomputers. M40, which Khotin was installing and programming, had only one kilobyte of RAM (random access memory) and 16 kilobytes of ROM (read only memory).

Instead of waiting to be ordered to visit the clients, Khotin travelled to the Moscow factory producing M40s. He managed to get the names and phone numbers of the client factories where the computers were to be distributed. His initiative, which earlier could have been subject to disapproval as divergence from the behavior of an average Soviet engineer, was backed up by the introduction of the khozraschet ideology in the Soviet Union, which emphasized independent economic accounting for the individual production units.

According to khozraschet, each Soviet enterprise should make ends meet on its own, requiring initiative and sales and marketing skills that had not been top priorities for Soviet factory managers. With the allocation list of M40 minicomputers in hand, brigade leader Khotin worried about the future of his job - started phoning factories, introducing himself, and offering help in M40 installations. This marketing campaign resulted in a long chain of work trips throughout the vast Soviet state. Khotin visited factories that produced anything from shoelaces to gunpowder and rockets, helping their staff unpack, install, connect, and program the new machines. However, with the years he grew tired of continuous traveling. Also, the state of affairs in the Soviet periphery differed drastically from the official rosy picture:

In the mid 1980s our brigade visited a factory in a Siberian town that was producing shells for Katyusha rockets. When we had finished our job in the evening and were about to return to the hotel, the factory engineer asked us to wait for a moment. He left the room and 
returned after a while with a one meter long sharpened metal stick. He insisted on walking us to the hotel, protecting our safety with this metal stick.

For Khotin's future career the time at LMNSU was important, not only in terms of gaining concrete though necessarily limited work experience but also in making new connections with the management of the Soviet factories. It was one of these managers who invited him to take a job as software director in a Russian-American joint venture in Leningrad in 1989, the next important step in Khotin's path toward founding his own software company.

\section{Gaining contacts and competences in the Russian-American joint venture Dialogue (1989-92)}

Dialogue was one of the very first Russian-American joint ventures Russians supplying the programmers and Americans the funding established in the Soviet Union. It had an office in both Moscow and Leningrad, and it worked as a Russian dealer for several Western IT companies, mostly selling computers and, among other things, conducting localization of MS Word and other Microsoft products. ${ }^{3}$ Khotin's role in the Leningrad office was to develop software projects inside and outside Russia. Getting projects outside of Russia was hard, so he focused on getting factory computerization projects in the Leningrad area.

The job at Dialogue was an eye-opening experience, exposing Khotin to a world totally different from his experience in the Soviet economy. It allowed him to, among other things, travel to New York and Boston as early as 1990, when visiting abroad was still impossible for all but a few people in the Soviet Union.

During his time with Dialogue, Khotin established a network of important connections, gained competences vital for conducting business, and got connected to the world outside the Soviet Union. The joint venture functioned as a nexus of contacts and a springboard for many future Russian businessmen such as Khotin's boss, Vitaly Savelev, who is currently the CEO of the Russian airline company Aeroflot. Khotin, who himself was asked to join Dialogue by his former client at LMNSU, continued the chain by inviting another former client of LMNSU to join Dialogue and, years later, to join Khotin's own software company.

The connections made during my years at Dialogue were very important and they still are. If you look at my LinkedIn network 
[a business-oriented social network site], you will see that many people in my network have had some relationship with this company.

Most importantly, Dialogue allowed Khotin to meet with and learn from many US businessmen. In the early 1990s there was a keen interest in Russian transition, and Dialogue had several high-caliber visitors. Among them was Bill Gates, with whom Khotin shook hands and talked during Gates' Russian trip where he was spreading his vision of getting computers 'on every desk'. Khotin learned both business skills and terms from these encounters and gained experience in speaking English. Every one of these encounters taught a former Soviet radio engineer something important, from the English language to Western business practices, and one of them also forced him to face an existential question:

I met a 17-year-old American student whose father had sent him to Russia to gain experience. He asked me what I am going to do in five years. That was first time anyone had asked me such a question and the first time I had ever thought about it. The Party was supposed to take care of us, so there had been nothing to think about. I realized that I had been living like a vegetable!

When conducting computerization in a factory located in Vyborg, a small town near the Finnish border, Khotin actively used the programming language Clipper, which was mainly used for database programming. Having gained considerable expertise in this language and being surrounded by Americans 'who believed that users had some rights', he founded the first Russian Clipper users group, which was joined by some two hundred Russian IT specialists. Having close contacts with this professional community later encouraged him in his decision to establish his own business:

One of the most important factors behind my decision to leave Dialogue and start up my own business was the idea that there were two hundred developers whom I knew and with whom I could work on projects. If I had been a single guy with no support, I probably would not have dared to do it.

Among the important lessons Khotin learned at Dialogue was how to communicate abroad through computers. The company built one of the first Bulletin Board System nodes in Russia and joined FidoNet - a network connecting Russian and foreign personal computers through 
modem and phone line - in the early 1990s when the Internet was not yet available in Russia. ${ }^{4}$ The first connection between the Russian nodes of the network to the West was established through the personal computer of a Finnish user who every night received data in a trunk call from his Russian counterpart for whom it was possible to phone abroad for free.

However, the commercial success of the joint venture did not come about as wished. The enthusiasm of the employees could not replace the lacking business skills and control of funds, only a part of which was used for business development. When Dialogue widened its sphere of activities and started trading 'all kinds of goods', Khotin began to look for other options, already having decided to start up his own company.

\section{Founding and early years of the software company Arcadia (1992-present)}

Khotin was invited to a teaching job at an educational institute in St. Petersburg in 1992, again by an acquaintance, also a former employee of Dialogue. The meager salary was compensated by the free use of a computer and free access to the Internet - both rare opportunities in the Soviet Union in the early 1990s. At Dialogue Khotin had already understood the importance of foreign contacts and learned to use the Internet, which knowledge he now put to use:

At that time one of my friends gave me a small laptop computer. Consequently, in the daytime I was teaching, while in the evening I was using computers and Internet at my office and at night browsed BBS world from that tiny laptop with just small floppy instead of HD.

(Cook 2009: 4-5)

Though the idea of his own software company had emerged for the first time already during his second or third year at Dialogue, the final decision was made in March 1993 in Khotin's kitchen, together with his wife, a professional programmer, and their daughter - all former graduates of the same technical university. The firm was named Arcadia, mimicking Khotin's first name, 'after 30 seconds of reflection' and the accountant, a key person in a Russian firm, was recruited from among the former students who had gone through summer training by his wife at her office at the university.

Khotin's experiences of Western connections from the Dialogue years and the lack of demand for software development services in domestic 
markets encouraged him to look for customers outside of Russia. He tried every possible channel to raise the interest of potential foreign clients through active e-mailing to various bulletin boards. Following up on an idea from a friend, he even sent an email in 1993 to the NBC nightly news, which was inviting viewers to send in e-mail messages from all over the world. This mail was read on air by the NBC news anchor, because it differed from the other 3000 messages sent in (Cook 2009):

Subject: From Russia with Love

Dear Americans,

My warmest seasons greetings from St. Petersburg Russia. Please keep up your great work in helping us to dig ourselves out from the deep hole that we got into about 70 years ago. I am sure it will be rewardable for both nations!

Cheers, Arcady Khotin

In addition to e-mails, Khotin started writing articles in Boardwatch magazine, one issue of which was read by the Florida-based US citizen Philip Schwartz, who asked Khotin to transmit a message from Schwartz' Russian friend to St. Petersburg. This contact started an intensive communication between the two men, which continues until today, and provided Khotin with an important mentor who advised him how to conduct business:

It turned out that we were same age and had similar interests in many areas. Philip and I began a very heavy e-mail communication over a period of weeks and then months and now even years. I was asking him tons of questions about how to do business. We called that e-mail stream Schwartz University. This was possible for me to accomplish in part because of the time shift. I would take care of my daily affairs and then send him e-mail. He would be up and running in Florida by late afternoon my time and we would exchange three or five or even 10 e-mails in a 24-hours period. He was extremely helpful. He sent me the modem, then a laptop, and then invited me over. He gave me invaluable help in developing my early business.

(Cook 2009: 9)

Finally one of Khotin's e-mails on a bulletin board was read by a US citizen from Long Island, who became his first customer. This first contract 
helped him to rent a two-room office on the outskirts of St. Petersburg, buy three computers, and hire three programmers from among his old contacts in the Russian Clipper user group.

The first contract, which was based on the fact that a good programmer's pay was at the time USD 150 a month in Russia, kept Khotin afloat but was not enough. Khotin continued his search for clients by following the Internet, reading articles in Computerworld or on BBS message boards and sending innumerable e-mails offering IT services. To overcome the trust gap, he volunteered to do some work for free, hoping that a happy customer would continue to work with him for pay. This was not, however, an easy effort, since he still lacked expertise in basic business practices such as how much to charge the customers, as the following recollection from 1994 shows:

I had no idea about how to speak at the terms of payment. I had no idea of the concept of things like retainers. My Soviet mentality did not allow me to ask. (...) when someone asked me how much I wanted to be paid for this activity, I had no idea how to arrive at an appropriate figure. I began to ask Philip for help and advice which he began to generously offer me. In trying to price a small project I had no idea how to say it would be about $\$ 500$ or it would be in the lower hundreds of dollars. Philip had software development experience and he was very good in helping me formulate proper estimates.

(Cook 2009: 9)

In addition to the problems with foreign business practices and customs, the domestic ones proved to be even more difficult. Starting as an entrepreneur in Russia was not easy in the early 1990s, when many basics for the normal running of a company such as computers, printing paper, or properly working phone lines were hard to get, unreliable, or expensive, regulations concerning business were constantly changing, and banks were unreliable and often bankrupting.

The domestic markets were riddled with corruption and violence and the cat-and-mouse game with tax inspectors was one of the many problems which had to be solved with the help of trusted social ties:

[personal contacts were used] to find out how to write a report to tax inspection. This was very important because our state agencies did not know what we were doing, they did not understand it. (...) For us it was enough to send the software to the client through the Internet. But the tax inspector did not understand what the Internet was. They 
suggested that we save the software on a diskette and send it by mail so that there would be a tangible product crossing the border. We started sending diskettes like fools but then someone realized that we could send state secrets on them - their contents should be checked at the corresponding state agency which could then authorize the sending. What idiotism! Well, we of course asked each other how you solve this problem, what do you write in the contract?

By 1996 Khotin had grown tired of flying three times a month to meet the US clients and started looking for customers closer to home. A natural choice was neighboring Finland, whose capital Helsinki was located only 300 kilometers west of St. Petersburg. Khotin decided to pay a visit to Finland in order to attend an IT seminar with his best programmer in 1996:

I had no money to pay for his seminar but I said look if I can make a presentation, will you let me in? He [the Finnish seminar organizer] said sure. (...) We went to the seminar and spent six hours listening to presentations in the Finnish language and then we made our own presentation in English. People were complimentary and I thought 'wow, we will get some projects' but we returned back to St Petersburg and nothing happened. I definitely had raised some interest but I had a zero marketing skills including a lack of understanding of how to follow-up. I even went without business cards. They said we will send you something but they did not even know my e-mail address. I was still a very inexperienced person.

(Cook 2009: 10)

Despite Khotin's inexperience in selling services, this conference led later on to an important contract with the owners of the Finnish antivirus company Data Fellows (currently F-Secure) which remains his customer to this day. Observing and learning from the Finns doing business has been a practical business school whose example Khotin is still in the process of applying to his own firm.

The fall of the Russian ruble in 1998 was a catastrophe for many Russians, but for Khotin and other software exporters whose customers paid in dollars, it meant a sudden and large rise in income. For the first time in his career, Khotin was able to hire staff - in addition to himself, an accountant, and a system administrator - whose hours were not directly billable from customers. The company joined the RUSSOFT association in 1999, and the 2000s have been marked by the growth of 
the company from the original four-man office to one of the major St. Petersburg software houses. Arcadia has, among other things, started its own recruiting agency, opened a Finnish office, and completed ISO certification. The growth also translates to the continuous need for keeping the hired programmers employed. Here, again, personal relations come in handy:

I am pulling all my strings. I have almost 600 connections on LinkedIn. To e-mail my contacts about the availability of these people I would search within LinkedIn for data security and throw in a few other appropriate terms to find a subset of my contacts in Scandinavia or in Russia to whom I would send e-mail. If the guys are in my network, I can send e-mail directly to them. If they are in the network of an acquaintance and look especially good, I can ask the acquaintance to help out. I knock on the door and say 'hey I have spare resources. Can you help me to find someone who can put them to work?'

(Cook 2009: 24)

In hindsight, all the phases in Khotin's professional career now seem to have been in some way beneficial for his future entrepreneurship. Work at the research institute introduced him to computers and programming, and the job at the state computing firm gave him practical experience in collaborating with enterprises. Particularly significant was the period at the joint venture Dialogue which connected him to the world outside the Soviet Union and taught him communication and linguistic and business skills. Most importantly during his time at Dialogue, he established a great number of both domestic and foreign contacts, such as the Russian Clipper user group and his US mentor Schwartz.

In all, Khotin's career testifies not only to his personal abilities but also to the power and reach of his personal network ties and the overlapping of the personal and professional spheres of life. Khotin was invited first to work at Dialogue by his former customer at the state computing firm and then to a teaching job by his former colleague at Dialogue. While at Dialogue, he himself recruited his former client from the state computing company to work with him, and founded a professional Clipper community, from which he later recruited his first programmers. Finally, the founders and key persons of Arcadia were selected in and through the trusted ties of family - a natural choice under the conditions in Russia in the early 1990s.

These ties and networks formed the social basis for Arcadia's birth and growth. But the story of Arcadia also illustrates how, in addition to the social aspects, the emergence and success of a post-Soviet Russian firm 
has to be placed and understood in historical perspective. This is what the next two sections try to do for the Russian IT sector.

\section{Computing in the Soviet Union}

The basis for Soviet computing and later post-Soviet Russian IT was already laid by the development of higher education and scientific research in imperial Russia. Though the turmoil of the 1910s and 1920s hampered progress, both mathematics and electronic engineering developed intensively in the 1920s and 1930s, stimulated by Lenin's famous GOELRO program (Gosudarstvennaia komissiia po elektrifikatsii Rossii) for building a nation-wide electricity distribution network in the Soviet Union. The strong growth of power engineering had great impacts on the early period of Soviet computing, whereas later on the computing needs of the Soviet military sector came to be of primary importance (Fitzpatrick et al. 2006).

The construction of the first Soviet digital computer MESM (Malaia Elektronnaia Schetnaia Mashina, 'small electronic calculation device') during the years 1947-51 under the leadership of S. A. Lebedev, one of the founding fathers of Soviet computing, illustrates well the material, organizational, and ideological constraints under which the pioneers of Soviet computing operated. ${ }^{5}$ Researchers of the history of computing even claim that 'no all-electronic computer was ever built under more difficult conditions' (Goodman 2003: 21).

Crowe and Goodman (1994) offer a vivid account of the struggles of Lebedev, who was appointed the director of the Institute of Energy of the Ukrainian Academy of Sciences, located in a former monastery in a suburb of Kiev, in $1946 .{ }^{6}$ Lebedev had already started working on electronic triggers and arithmetical research related to computing systems in 1939, but the Second World War interrupted his work. The work by his institute was slowed down by the shortage of materials in the wartorn country, as it was unable to deliver the needed quantity and quality of components. Lebedev also had to fight the administrative, ideological, and science policy barriers, the protagonists of analog computing, and, in the 1950s, with a competing Soviet computer design project, 'Arrow' (Strela). ${ }^{7}$ When building MESM, Lebedev had to convince the Soviet leadership and scientific community of the importance and future of digital computing, which at the time was evident in neither the Soviet Union nor the US.

Despite the obstacles, MESM solved its first simple problem on November 6, 1950, was exhibited to a commission of scholars from the 
Ukrainian Academy of Sciences in January 1951, and was accepted into full operation in January 1952 (Crowe and Goodman 1994).

In the 1950s Lebedev moved to Moscow and continued his work, first with a new high-speed computer, BESM (Bystrodeistvuiushchaia Elektronnaia Schetnaia Mashina, 'high-speed electronic calculating machine'), and then from 1954 onwards with M-20, a computer based on germanium diodes, which would replace the unreliable vacuum tubes of the earlier models. ${ }^{8} \mathrm{M}-20$ was completed in 1958, about the same time as a project named BESM-2, and its serial production started in Moscow in early 1959 (Crowe and Goodman 1994). The beginning of the production of M-20 computers marked the starting point for the development of the Soviet computer industry, and stimulated the production of a series of M-20 compatible computers. In 1961 the M-20 computers' users association, the first professional association of computer specialists in the Soviet Union, was established (Prokhorov 1999: 5-7). ${ }^{9}$

During the Cold War, military reasoning gained a primary position in the development of Soviet computing. Military computing had special requirements for the components, which also had to be domestically produced. The beginning of commercial production of Soviet transistors in 1956-8 started the production of special computers adapted to military purposes (Khetagurov 2001: 192). The large share of these specialized military computers was a particular feature of Soviet computing, and, according to Susiluoto (2006: 147-8), even the universal computers were mainly used for military purposes.

Three military programs (nuclear weapons, ballistic missiles, and antimissile defense) dominated not only post-war Soviet computing, but also Soviet science and technology more generally. Their importance is illustrated by a quote from the Soviet cosmonaut Grechko recalling his experiences of working in the mid 1950s at the Academy Computation Centre on the BESM:

Kurchatov's people [nuclear weapons researchers] used it in the daytime and during the night Korolev's people [designers of ballistics missiles and spacecraft]. And for all the rest of Soviet science: maybe five minutes for the Institute of Theoretical Astronomy, maybe half an hour for the chemical industry.

(Harford 1997: note 54, 220, cited in Gerovitch 2001: 269)

The tremendous investment of resources in the military sector in the Soviet Union produced well-known achievements in the areas of space flight and military technology, among others, at the expense of the 
consumption and daily life needs of the general population. According to Manuel Castells, between 1940 and 1960 Soviet mainframe computers were not very far behind the achievements of the West, ${ }^{10}$ but in 1965 the country's leadership decided to shift from developing its own production to imitating Western computer technology - in the late 1960s and 1970s copying the architecture of the IBM 360 (Crowe and Goodman 1994: 11). ${ }^{11}$ As a result of this decision the USSR's information technology sector became dependent on copying chiefly American technology and began to lag more and more behind the development of the West.

Castells' assessment, based on his research both in Soviet and postSoviet Russia, is in line with that of the US experts from 1988 (Global Trends in Computer Technology, 1988). According to this report, in the late 1980s the Soviet Union was lagging years behind the West in most areas of computing, with possible exceptions in the theory of programming languages and information retrieval systems. ${ }^{12}$

Many of the reasons for the backwardness of the Soviet computing industry were the same as for that of the Soviet economy in general. Not only did the individual Soviet factories not necessarily know what to do with computers but they also had little incentive to be more efficient than what was required to fulfill the plan. There was a shortage of high-quality components needed for reliable hardware production, service for hardware and software was poor or lacking, and the ideological control of information did not fit the needs of the new economy, increasingly based on the processing of information (Global Trends in Computer Technology, 1988).

The excessive demand and lack of competition allowed the production units to continue their Soviet-era habits of production, and the complex and overlapping organization of the industry led to catastrophic shortages:

The production of floppy disks has been a disaster. Production was assigned to four different ministries with the brunt of the task falling on Minpribor. However, at the lower levels in Minpribor, there was a scramble to find productions space, and the full capacity of 50 million diskettes per year will not be reached before 1989. (...) The end result is a great shortage of diskettes.

(Global Trends in Computer Technology, 1988: 159)

In addition to problems of organizing production, Soviet computing also had to balance between ideological and pragmatic aspects of the field, 
which was to have lasting consequences for its development. According to Gerovitch (2001), computing scientists and professionals in the Soviet Union were torn by the contradictory requirements of emulating and surpassing American computing on the one hand and keeping at a distance from cybernetics, which was ideologically discredited in the Soviet Union as reactionary pseudo-science, on the other. This tension was solved through a discursive strategy of distancing computing from cybernetics. This had, however, long-term impacts on Soviet science by limiting computer uses to mathematical physics:

Soviet specialists in 'machine mathematics' had to walk a fine line between two mortal dangers - falling behind the West in computing, and following Western trends too closely. To avoid unwanted associations with controversial American cybernetics, they chose to 'de-ideologize' Soviet computing and place emphasis on the narrow technical functions of computing and information theory, ignoring any potential conceptual innovations. This strategy severely limited the field of prospective computer applications. The computer was legitimized in this Soviet context as a giant calculator; its capacities as a data processor for economic and sociological analysis, and as a tool for biological research, were downplayed, to avoid ideological complications.

(Gerovitch 2001: 279)

In order to meet the ideological requirements, the Russian translations of Western computer literature were furnished with introductions condemning the ideological errors of these publications and the most dubious parts were just left out. Domestic publication of computer-related works was prevented both by a fear of revealing state secrets as well as helping out rival Soviet computing programs. Only after Khrushchev's rise to power was cybernetics rehabilitated and legitimized (Gerovitch 2001: 270-5).

As a combined result of the problems and weaknesses described above, the Soviet Union missed the explosive growth of personal computing taking place in the West during the 1980s. While in the US interactive and user-friendly personal computers were revolutionizing office work, home entertainment, and computer-mediated communication, this development was absent in the Soviet Union. According to the estimate of a firm negotiating an agreement to sell computers to the USSR, and the information published by the New York Times, the USSR had 50,000 personal computers in 1988 - one for every 5600 people - while the US 
had roughly 30 million PCs - one for every 8 people (Global Trends in Computer Technology, 1988). ${ }^{13}$ The assessment of the missed chances in the Soviet Union by US experts in 1988 is devastating:

[T]he phenomenal growth of the PC in the United States depended on the characteristics and availability of the PC and its software, the demand environment, and marketing effectiveness. The PC offers such dramatic gains in simple areas such as maintaining a mailing list, generating form letters, doing word processing, and tracking budgets, to name but a few central applications, that it has become as indispensable to the office as the telephone and the copying machine. None of these conditions has been present in the Soviet Union. The Soviets have been unable to mass produce a reliable personal computer on the order of the IBM-PC, and support service is questionable at best. (...) The software distribution system is convoluted, and good software often never receives distribution because of the lack of copyright protection. Lower-level managers have far less autonomy, have not received any training in computing, and have little desire to start using computers. Generally speaking they are not in a data-rich environment where they could connect PCs to mainframes or networks. The individualistic and entrepreneurial strains are generally missing from the Soviet culture, and the absence of any home computers, for all practical purposes, has precluded the possibility of the emergence of the home computer phenomenon so familiar in the West.

(Global Trends in Computer Technology, 1988: 160)

In the spirit of perestroika, many problems of the computing industry could be discussed publicly, and attempts at reorganizing the field of the Soviet computing industry were made by creating two new organizations in 1986: the State Committee for Computing and Informatics was to coordinate and develop Soviet computing and promote the use of computers in the economy; and the Interbranch Scientific Technical Complex for Personal Computers was established to address the problem of continuity in the research and development cycle and the problem of ministerial departmentalism. Both institutions had to struggle with the already existing Soviet organizations and their results were meager (Global Trends in Computer Technology, 1988).

The collapse of the Soviet Union finally brought to end these and other experiments to revive the Soviet system from the inside. 
According to Manuel Castells (2000), information technology played a notable role in this collapse, and this role will be the subject of the next section.

\section{Information technology and the collapse of the Soviet Union}

Castells bases his interpretation both on his own fieldwork in the Soviet Union during the years 1989-96 and on the studies conducted by his wife, Emma Kiselyova (Castells 2000: 5).${ }^{14}$ After Castells and Kiselyova the development of post-Soviet Russia's IT sector has, with a few rare exceptions, been studied chiefly by private companies and market research departments. Exceptions in the area of information technology are, for example, Castells 2000; Gaslikova and Gokhberg 2001; Averin and Dudarev 2003; Hawk and McHenry 2005; Lonkila 2006; Rantanen 2001; and Susiluoto 2006.

In Castell's interpretation a central reason for the Soviet Union's bankruptcy was the inability of the Soviet economy, or, in Castell's terminology, the centrally planned 'industrial statism', to mold itself to the demands of a new economy based on information processing. ${ }^{15}$

Purely from the viewpoint of extensive economic growth, the growth of the Soviet Union's economy after the Second World War was a success story - although it was bought at the expense of human suffering and overuse of natural resources. According to Castells, for the greater part of its history the Soviet Union's economic growth was in fact larger than in Western countries and the speed of the country's industrialization is unequalled in world history.

Comparative growth abated only in 1975 and came to a standstill in 1980. Because of the absence of the price mechanism, the economy's resources were not allocated efficiently, and Soviet citizens became accustomed to life in a shortage economy. Nor was the economy able to develop internationally competitive, non-military products: the role of the Soviet Union in the international market became the massive export of raw materials, especially oil and gas which, coming into the 1980s, comprised 90 percent of the USSR's exports to capitalist countries (Castells 2000: 10-24).

Most catastrophic, however, was the drop-off in the speed of technoscientific development. The primary reason for this was the hegemony of the military-economic complex as well as an untenably large defense budget, which in the 1980s was about 15 percent of the gross national product - proportionally about twice as much as Reagan's government 
comparatively spent. The complex siphoned off both the best material and human resources from productive use, but it did not produce a spin-off effect on the side of the civil economy. The Soviet economy's priorities were always the security needs of the Soviet state as defined by the military-economic complex, and the fundamental conservatism of the security ideology would not tolerate the risk-taking necessary for an innovation-based new economy.

In addition to the central role of the military-technological complex, another important reason for the failure of the Soviet economy was the lack of an innovation system. The rigid centrally managed planning system, international differentiation, and lack of competition did not compel innovation and risk-taking, but rather led to the organization of production in the accustomed way. The Soviet Union's science academy was disconnected from the production plants, the research and development of which were based on each ministry's own research institutes. These in turn were not in contact with each other with the exception of an unsuccessful experiment in the Khrushchev era at the end of the 1960s.

Finally, the information-technological revolution did not fit together with the Soviet system's bureaucracy and ideological repression. Only a few Soviet scientists got to participate in international congresses, and the free circulation of information important for innovation was far from the Soviet system, where the use of typewriters and copy machines was tightly supervised. The new networked style of production could not be conciliated with the concentrated, hierarchical command economy (Castells 2000: 5-37).

If information technology had an impact on the demise of the Soviet Union, it also helped to save the fragile Russian democracy during the August putsch in 1991. Based on his interviews with key players, Rafael Rohozinski (1999: 1-2) describes in detail how the programmers of Relcom/Demos, one of Russia's private Internet providers, were among the first to testify to the coup from their offices near the Kremlin, and started transmitting the information to network nodes across the Soviet Union:

Within hours, they had established a temporary network node at the White House and were e-mailing Yeltsin's defiant declaration, rejecting the legitimacy of the coup committee to Russia's regions and abroad (...) By evening, the Relcom network was acting as a major channel of information between Moscow and the regions, linking the multitude of major and minor actors opposed to the coup. (...) As 
local and republican press organs increasingly drew upon Relcom for information about the unfolding drama in Moscow, the information vacuum, a key factor in the coup plotters' game plan, was filled.

(Rohozinski 1999: 1-2)

The whole story of the collapse of the Soviet empire with its ensuing transformation of economic, political, and geographical orders in the 1990s will not be reproduced here. Suffice it to say that the collapse of the economy destroyed the state budget which in its turn shattered the financial base of Russian scientific and research institutions. Some of them, however, managed to find a niche in the post-Soviet Russian ICT field, the description of which is the focus of the final section of this chapter.

\section{The ICT sector in the Post-Soviet Russian economy}

\section{The role of the ICT sector in Russia's national economy}

When assessing the role of the Russian ICT industry in the economy one has to bear in mind that it has, similar to other private enterprise in Russia, functioned for only under 20 years, and was born in the 1990s under particularly difficult conditions. ${ }^{16}$ The emergence of the Russian ICT field coincided with the global shift from mainframe to personal computing. This shift created a need for private companies providing system integration and software development services for the new platforms and contributed to the formation of the industry (Terekhov 2003: 22).

Despite the recent tendency of Russian software companies toward regionalization, the Russian ICT industry is geographically concentrated in relatively few centers, of which St. Petersburg, the location of our data collection, is the most important after Moscow. Though the St. Petersburg ICT market and companies are clearly smaller than in the capital, the city has been at the forefront of information technology, telecommunications and electronic engineering since imperial Russia through the Soviet Union and post-Soviet Russia: Russia's first phone line was erected between St. Petersburg and Gatchina in 1882 (Sokolov 1992: 66) and Alexander Popov presented his radio receiver to the Russian Physical and Chemical Society in St. Petersburg in 1895.

In the Soviet Union, within the frame of the planned economy, a considerable amount of radio engineering, telecommunications, and electronics industry and research was located in northwestern Russia, and at the end of the 1980s more than 50 industrial enterprises and 
scientific research organizations operated in Leningrad (Averin and Dudarev 2003: 37-8).

The St. Petersburg/Leningrad region also played an important role in the recovery of the post-Soviet Russian economy after the collapse of Soviet industrial enterprises and research organizations. Due to its geographical proximity to Western Europe, availability of educated workforce, and long traditions in the field, northwestern Russia was a central player in the development of the Russian IT industry and mobile telecommunications. The first cellphone call in post-Soviet Russia, for example, was made by the St. Petersburg mayor Anatoly Sobchak through the operator Delta Telecom in 1991, and the main optical fiber connecting the Russian Federation to Europe and the rest of the world goes through St. Petersburg and Finland. Several large international companies in the ICT related fields, such as HP, Siemens, LG, Microsoft, Google, Sun, and Intel, operate in the St. Petersburg area (Kärkkäinen 2008: 70-81).

Today the Russian ICT industry is a small but rapidly developing sector of the economy, which until recently has stayed in the shadow of the energy sector. The ICT sector's relatively small proportion of the economy (5 percent of the gross national product in 2005, according to the minister of communications Leonid Reiman) ${ }^{17}$ has been compensated by its extremely rapid growth during the 2000 s. ${ }^{18}$ One of the main engines of this growth - together with the general boost to the Russian economy fueled by rising oil prices - has been the development of the telecommunications field, particularly cellphone use, in Russia.

In the 1990s cellphones were still out of reach of the general population because of both the high prices of phones and the high tariffs, and they were chiefly considered symbols of the nouveaux riches and organized crime. After the economic crisis of 1998 and especially in the 2000s, prices fell as competition was freed, cellphones lost their elite character, and their use exploded (Gladarev and Lonkila 2008). As a result, telecommunications accounted for 70 percent of the ICT sector in 2007 (see Table 3.1).

Within the IT sector, the table shows how hardware's proportion of the total IT markets diminished from 66 percent in 2003 to 56 percent in 2007, while during the same time the proportion of software development grew from 13 percent to 18 percent, and that of services from 21 percent to 26 percent.

As the example of Ireland shows, software exports may function as an important source of foreign currency revenue in a national economy. 
Table 3.1 The development of Russian ICT markets 2003-7, bn USD

\begin{tabular}{|c|c|c|c|c|c|c|c|c|c|c|}
\hline & \multicolumn{2}{|c|}{2003} & \multicolumn{2}{|c|}{2004} & \multicolumn{2}{|c|}{2005} & \multicolumn{2}{|c|}{2006} & \multicolumn{2}{|c|}{2007} \\
\hline & $\begin{array}{l}\text { bn } \\
\text { USD }\end{array}$ & $\%$ & $\begin{array}{l}\text { bn } \\
\text { USD }\end{array}$ & $\%$ & $\begin{array}{l}\text { bn } \\
\text { USD }\end{array}$ & $\%$ & $\begin{array}{l}\text { bn } \\
\text { USD }\end{array}$ & $\%$ & $\begin{array}{l}\text { bn } \\
\text { USD }\end{array}$ & $\%$ \\
\hline Hardware & 4.6 & 66 & 5.4 & 61 & 6.6 & 61 & 8.1 & 59 & 9.9 & 56 \\
\hline Software & 0.9 & 13 & 1.1 & 12 & 1.5 & 14 & 2.2 & 16 & 3.1 & 18 \\
\hline Services & 1.5 & 21 & 2.4 & 27 & 2.8 & 26 & 3.5 & 25 & 4.6 & 26 \\
\hline IT total & 7.0 & 100 & 8.9 & 100 & 10.9 & 100 & 13.7 & 100 & 17.6 & 100 \\
\hline Telecommunications & 12.9 & & 18.8 & & 23.3 & & 31.7 & & 40.5 & \\
\hline ICT total & 19.9 & & 27.7 & & 34.2 & & 45.4 & & 58.1 & \\
\hline$\%$ telecomm of ICT & & 65 & & 68 & & 68 & & 70 & & 70 \\
\hline
\end{tabular}

Source: Minkomsviaz' (2009)

Table 3.2 Software exports' proportion of the Russian IT sector 2003-7, bn USD

\begin{tabular}{lllrrr}
\hline & 2003 & 2004 & 2005 & 2006 & 2007 \\
\hline Russian IT sector * & 7.0 & 8.9 & 10.9 & 13.7 & 17.6 \\
Software export ** & 0.5 & 0.8 & 1.0 & 1.5 & 2.2 \\
Software export \% of IT sector & 7.8 & 8.5 & 8.9 & 10.6 & 12.5 \\
\hline
\end{tabular}

Sources: Minkomsviaz' (2009); ${ }^{* *}$ RUSSOFT Annual survey, 2007

Though the value of Russian software exports has been modest, their proportion of the whole IT sector grew steadily during the first decade of the 2000s (see Table 3.2).

The clear majority of the Russian software export income in 2007 came from software development services (58 percent), followed by sales of products and solutions (25 percent) and from international companies' development centers in Russia (18 percent) (RUSSOFT Annual Survey, 2007: 12). The export of ready-made products was very concentrated: four companies accounted for over half of Russian software exports including, in addition to ABBYY products, Kaspersky Lab (antivirus programs), CBOSS (billing systems) and Transas (navigation systems, vessel traffic management systems, marine and aviation simulation systems) (RUSSOFT Annual Survey, 2008).

On average the Russian IT companies are small in comparison with international firms both in terms of sales and number of employees (see Table 3.3). Notable exceptions are such Moscow-based firms as Luxsoft, EPAM, and Exigen which employ 2000-5000 people each. The software companies based in St. Petersburg were clearly smaller than 
Table 3.3 Median number of employees in the 100 biggest Russian IT companies 2003-7

\begin{tabular}{llllll}
\hline Year & 2003 & 2004 & 2005 & 2006 & 2007 \\
\hline Median no of employees & 204 & 209 & 300 & 368 & 403 \\
\hline
\end{tabular}

Source: CNews Analytics (2010)

their Moscow counterparts; none of them ranked among the 10 biggest Russian IT companies. The largest of the St. Petersburg companies employ only some hundred people and include companies such as Reksoft, DataArt, Digital Design, Arcadia, and Lanit-Tercom. ${ }^{19}$ Of the 30 leading IT companies in northwestern Russia, the sales of the biggest one, BCC, amounted to 3,685,500 thousand roubles (roughly 142 million USD) in 2006 and it employed 720 people (CNews Analytics 2007).

These impressions of the comparatively small size of Russian IT companies are supported by a 2008 survey directed at companies who were to some extent involved in exports of software products and services from Russia. Of the 96 companies who responded to the survey, 47 percent employed up to 30 people, 43 percent from 30 to 500, 5 percent from 500 to 1000 and 5 percent more than 1000 people. In terms of turnover, 43 percent of these firms had up to 0.5 million USD, 47 percent from 0.5 to 10 million and only 10 percent over 10 million USD.

\section{ICT use in Russia}

Though the figures on ICT use in Russia vary depending on the source and methodology, the general trend has been that of extremely quick growth. Chachin (2008), for example, estimates the growth rate of Internet users in 2006-7, based on the data from Russia's ministry of communications, at 50 percent, the number of PCs at 36 percent, and number of households' broadband access at more than 50 percent.

Figure 3.1 shows the development in the use of Internet, personal computers, and mobile phones in Russia during the 2000s based on data from the Levada Center surveys. ${ }^{20}$

Despite the rapid growth, the general level of ICT use in Russia is still weak according to the international 'network readiness index'. This index - which combines evaluation of the regulatory macroeconomic environment with the readiness and usage of ICT by individuals, business, and government - positioned Russia in 2007-8 at 72, between Vietnam (73) and Kazakhstan (71). In the same list Denmark was 


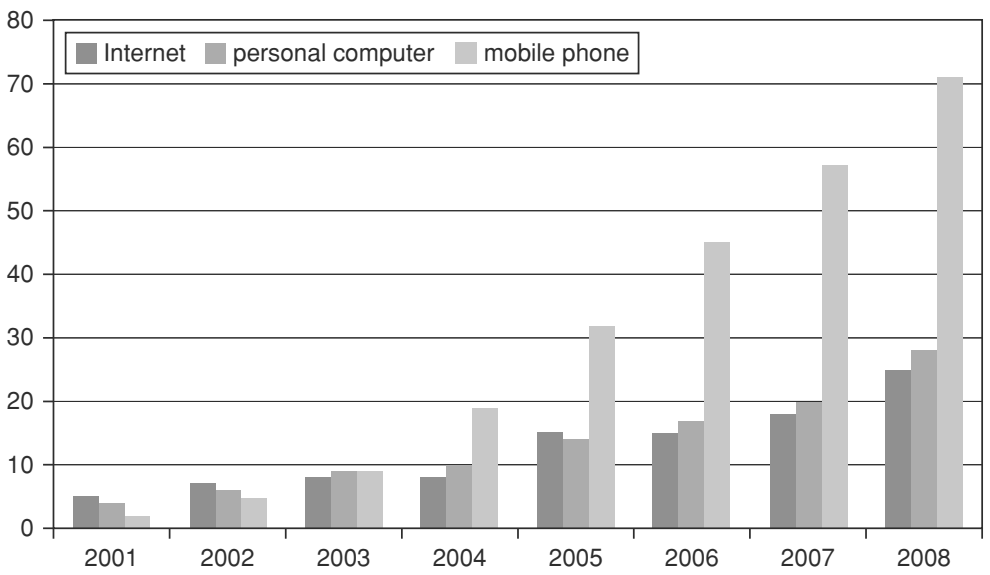

Figure 3.1 The use of Internet, personal computers and mobile phones in Russia, $\%$ of population

Table 3.4 The use of Internet in selected European countries in 2008, \%

\begin{tabular}{lcccrr}
\hline & Germany & Finland & France & UK & Russia \\
\hline No access at home or work & 22 & 12 & 22.5 & 21.1 & 62.4 \\
Never use & 8.8 & 13.7 & 10.6 & 7.5 & 7.6 \\
Less than once a month & 1.6 & 1.5 & 1.3 & 2.6 & 2.5 \\
Once a month & 1.1 & 1.4 & 1.4 & 1.3 & 1.3 \\
Several times a month & 6.1 & 2.6 & 2.4 & 4.2 & 3.1 \\
Once a week & 4.8 & 6 & 3.2 & 4.2 & 2.3 \\
Several times a week & 17.2 & 16.5 & 12.8 & 15.9 & 8 \\
Every day & 38.3 & 46.3 & 45.7 & 43.3 & 12.7 \\
Total & 100 & 100 & 100 & 100 & 100 \\
\hline
\end{tabular}

Source: European Social Survey (2008)

first, the US fourth, Finland sixth, and the UK twelfth (Dutta and Mia 2009).

This impression is further reinforced by the results of the latest round of the European Social Survey offering comparative data on Internet use in Europe (Table 3.4).

The question was 'how often do you use the Internet, the World Wide Web or e-mail - whether at home or at work - for your personal use?'

The table shows clearly that Internet use in Russia is lagging far behind the level of Western European countries. Internet use is also unequally divided in terms of geography, education, and income, and 
Internet access is still hampered by the deficiencies of the old telecommunications infrastructure.

Moreover, the Russian Internet is at least potentially subject to state control: while the original SORM legislation (Sistema OperativnoRozysknykh Meropriiatii, 'System for Operational-Investigative Activities') allowed officials to record all phone discussions, its updated version SORM-2 authorizes FSB to access all Internet Service Providers' computers or other devices in order to monitor Internet traffic (cf. Alexander 2004: 616). In practice the amount of Internet traffic limits the realization of state control (see Alexander 2004 for a closer account of SORM and Russian Internet policy). ${ }^{21}$

\section{State support for the Russian ICT industry}

The state can have different kinds of roles in the development of ICT industry. At the center of Finland's information society model, for example, has been a state-mediated relationship between the public and private sectors, in which the state has purposefully supported a politics of innovation both directly and through the universities and research institutes (Castells and Himanen 2001; see also Fligstein 2001). ${ }^{22}$

Throughout the 2000s Russia's government as well has, at least in public speeches, recognized the economic, strategic, and political aspects of the ICT sector, which has manifested in, for example, the Federal Program Electronic Russia covering the years 2002-10. The program was approved by the Russian government in 2002 with a total budget of 2.6 billion USD. It aimed at increasing the effectiveness of government operation, developing the information transparency of the authorities, improving industry legislation and stimulating higher ICT related education. The first results did not, however, meet expectations. The program budget was cut twice in 2003 and its actual outcomes remain unclear (Averin and Dudarev 2003: 109; Susiluoto 2006: 305-6).

During the 2000s there have been further state initiatives to boost non-energy-related areas of the Russian economy, such as the creation of 'special economic zones', 'technology parks', and venture investment funds and plans of reduced tax burdens on export-oriented Russian IT companies (Wilson 2007; Stewart 2008). ${ }^{23}$ Assessing these efforts, Gianella and Thompson (2007: 25-6) estimate, however, that without coordination between various state bodies, close monitoring of the budgetary funds, and evaluation of the effectiveness of the projects, there is a risk of duplication of effort, waste, and rent-seeking.

This assessment is in line with the opinion of the authors of the Russian Software Developers Association's report from 2008, based 
on the annual survey of 96 Russian software-exporting companies. The general views of the companies on the business environment are devastating: a high number of companies gave 'poor' marks for most of the aspects inquired about, such as human resources availability and education system (52 percent), taxation system (45 percent), impact of bureaucratic and administrative barriers on business (63 percent), availability of up-to-date infrastructure (52 percent), financial support to start-ups (67 percent), and state support of international marketing activity (75 percent). These numbers clearly reveal the failure of the Russian state to markedly support working conditions for the software industry. Even in the cases where measures have been taken, as the examples of the e-Russia program and technology parks above show, they have failed to produce substantial results:

Still there is no significant progress in implementation of projects on technology parks construction specifically for IT companies (including software developers) with state financial support. Design and construction of technology parks in some cities is already in progress. But it goes slowly and the terms for property construction are constantly shifted. Besides, initiators of these projects have little understanding of the final results. There are reasons to assume that within the framework of technology parks ordinary business would be constructed (not only for IT companies).

(RUSSOFT Annual Survey, 2008: 22)

This is also the case with taxation, where the law on reduction of the Unified Social Tax for software exporters from 26 percent to 16 percent turned out to be inconsistent with Russian pension legislation. Neither has an amendment in the Russian Federation Tax Code exempting value-added tax on sales of licensed software worked in practice (RUSSOFT Annual Survey, 2008: 20).

The authors of the report estimated the situation of the creation of special economic zones, where residents and high-tech companies are granted special privileges, in somewhat brighter terms, but saw no significant progress in the development of 'science cities' in which research centers were supposed to receive additional funding from local and federal budgets (RUSSOFT Annual Survey, 2008: 22).

According to the survey, Russian ICT firms consider bureaucratic and administrative barriers to be one of the most important business problems. As noted, 63 percent of firms in the survey described the level of solving bureaucratic and administrative barriers as 'poor', and particularly the St. Petersburg-based firms were among those affected by 
the Russian bureaucracy. One example, given by the survey authors, was the difficulty in recruiting foreigners:

The existence of barriers for recruitment of foreign staff in Russian companies looks absolutely illogical. Sometimes the inviting Russian party has to spend up to six months to formalize all required documents to make it possible for such specialist to work for one year in Russia. Some companies are ready to attract experienced foreigner or former Russian citizens to use their expertise and knowledge to arrange sales of ready-made solutions and products on the world markets. But they do not dare to undertake these steps precisely due to complicated bureaucratic formalities.

(RUSSOFT Annual Survey, 2008: 21-2)

Though a third of the firms in the RUSSOFT 2008 survey did note an improvement in state support of IT in the last two years, ${ }^{24}$ the authors of the report consider this number to be based on hopes of the industry being finally taken seriously and supported by the state. According to the authors, however, no substantial results have been reached:

The situation was seriously aggravated by the fact that the new Government did not include a ministry responsible for information technologies. The former Ministry of Information Technologies, and Communications was transformed into the ministry of Mass Communications losing IT in its official name.

(RUSSOFT Annual Survey, 2008: 25)

In addition to the bleak estimates of the situation in 2008, most parameters of the business environment for software development companies had slightly worsened or remained the same in comparison with 2007 with the lone exception of property rights. However, the report also concludes that the difficulties hit the medium-sized companies hardest whereas a group of large companies - also facing a lot of problems - had 'more opportunities to overcome them', as the authors ambiguously remark (RUSSOFT Annual Survey, 2008).

To summarize, and in line with the crushing statement of President Medvedev cited in the introduction of this book, the available evidence suggests that the Russian state has so far failed to notably support the development of the IT field.

\section{Russia's position in the global ICT market}

The Russian share in the global IT market is estimated at between 1 percent and 3 percent (Russian ICT market overview, 2007). Russia does 
not have significant, globally competitive hardware production nor with some exceptions, such as the document conversion, data capture, and linguistic software produced by the company ABBYY - breakthrough software applications competitive in the global mass market. Instead it is likely that many software products marketed as Western contain the work of Russian offshore programmers.

Michael A. Cusumano (2006) considers Russia's position in the distribution of labor in the global software industry in comparison with the situations of Europe, India, and Ireland:

Where does Russia fit into the global software business? Will companies there go the way of many other European firms and emphasize the science more than the business, and on expertly meeting the needs of local industry, but encounter limited success in global product markets? Will Russia go the way of India and emphasize service companies that will do anything the client wants at highly competitive prices but fail to build a products-based business? Will Russia become a lower-cost Ireland, with many small companies and lots of technical expertise, but too much emphasis on leisurely lifestyles and independence from venture capital and the stock markets?

(Cusumano 2006: 33)

He concludes that Russia's competitive advantage lies in the ability to perform very sophisticated technical work at relatively low cost.

In line with Cusumano's conclusion, the high quality of Russian information technology professionals' mathematical competence is commonly recognized. One indication of this competence is the position of Russian students in the International Collegiate Programming Contest. The contest was won in 2009, 2008, and 2004 by the St. Petersburg State University of Information Technology, Mechanics and Optics, in 2006 by Saratov State University, and in 2001 and 2000 by St. Petersburg State University, with other Russian universities commonly occupying other top positions in the contest. ${ }^{25}$ Considering the results of the contest, it is evident that top-level programmers are trained in Russia in Saratov, Perm, Izhevsk, Stavropol, Yekaterinburg, Novosibirsk, Ufa, Barnaul, Orel and Petrozavodsk, and about ten other Russian cities as well as Moscow and St. Petersburg (RUSSOFT Annual Survey, 2008: 33-4).

The competitive advantage created by a high quality workforce is reduced by deficiencies in the project management and English language skills of university graduates. On the macro level the obstacles to the development of Russia's ICT sector are, among others, the 
prevalence of pirating, ${ }^{26}$ poor infrastructure, underdeveloped legislation, the corruption of the public sector, and the bad image of the Russian state abroad along with its intrusion into the economy. ${ }^{27}$

Moreover, the quick growth of the ICT sector, the concentration of activity in a few centers, particularly Moscow, St. Petersburg, and Novosibirsk, and the arrival and establishment of foreign companies (such as Sun, Microsoft, Alcatel, Motorola, Intel, and HP) in Russia have led to intensifying competition for skilled programmers. The rapid growth of demand together with a limited supply pool has led to a quick rise in salary levels in the early 2000s. ${ }^{28}$ Competition for competent workers also forces employers to organize their business activities better. For example, in order to get a bank loan, an employee needs a steady job and an officially paid 'white' salary. In addition to the salary, workers have begun to value social security and health care benefits paid by their employers.

The rise in wages has led to a reduction in the relative cost advantage of offshore programming done in Russia. This has forced companies, especially those concentrating on cheap outsourcing of programming, to develop new business models, such as orientation to the domestic market, establishment of branches outside of the Russian metropolises in places with cheaper labor (other Russian cities and former USSR countries, but also in Scandinavia and Western Europe), attempts to develop their own products and applications, and attempts to reach closer partnerships with customer companies. However, closer cooperation with customers also demands substantial domain knowledge from different fields. The ability of Russian offshore firms to acquire such knowledge and integrate themselves deeper into the business processes of the end customers may turn out to be decisive for the industry's future.

In all, the Russian ICT industry is, despite its small size, a strong and fast-growing field of the economy, with the telecommunications sector having a leading role. In terms of human resources, it also seems to have the potential to capitalize on Russian scientific and mathematical competences for the uses of economic diversification. But as the short review of the history of the field showed, the roots of the industry in many ways date back to the Soviet era. This rooting has commonly been referred to as the Soviet legacy or heritage. The next chapter turns to the analysis of the nature of this legacy, drawing both on the existing research and our own empirical data. 